\title{
Psychological morbidity in Nepali cross- border migrants in India: a community based cross-sectional study
}

Raja Ram Dhungana ${ }^{1,2^{*}}$ D , Nirmal Aryal ${ }^{3}$, Pratik Adhikary ${ }^{1,4}$, Radheshyam Krishna KC ${ }^{5}$, Pramod Raj Regmi ${ }^{3}$, Bikash Devkota ${ }^{6}$, Guna Nidhi Sharma ${ }^{6}$, Kolitha Wickramage ${ }^{7}$ Edwin van Teijlingen ${ }^{3}$ and Padam Simkhada ${ }^{3,8}$

\begin{abstract}
Background: Since Nepali cross-border migrants can freely enter, work and stay in India, they are largely undocumented. The majority is involved in semi-skilled or unskilled jobs with limited labour rights and social security, a fact which predisposes them to psychological distress. We aimed to assess the prevalence of and factors associated with psychological morbidity among Nepali migrants upon their return from India.

Methods: A community based cross-sectional study was conducted in six districts of Nepal between September 2017 and February 2018. A total of 751 participants who had worked at least six months in India and returned to Nepal were interviewed from 24 randomly selected clusters. The General Health Questionnaire (GHQ)-12 was used to measure the psychological morbidity. Data were analysed using Poisson regression analysis.

Results: The majority was younger than 35 years (64.1\%), male (96.7\%), married (81.8\%), had at least a primary education (66.6\%), and belonged to Dalit, Janajati and religious minorities (53.7\%). The prevalence of psychological morbidity was $13.5 \%$ (Cl: 11.2-16.1\%). Participants aged 45 years and above (adjusted prevalence ratio $(\mathrm{aPR})=2.74)$, from the Terai $(a P R=3.29)$, a religious minority $(a P R=3.64)$, who received no sick leave $(a P R=2.4)$, with existing health problems $(\mathrm{aPR}=2.0)$ and having difficulty in accessing health care $(\mathrm{aPR}=1.88)$ were more likely than others to exhibit a psychological morbidity.

Conclusion: This study demonstrated that psychological morbidity was prevalent in the study participants and varied significantly with individual characteristics, work conditions and health. Multifaceted approaches including psychological counselling for returnees and protection of labour and health rights in the workplace are recommended to help reduce psychological morbidity.
\end{abstract}

Keywords: Migrant workers, Prevalence, Psychological morbidity, India, Nepal

\section{Background}

Migrant workers are likely to experience adverse conditions that can influence their health and wellbeing in every phase of migration [1]. Post migration experiences such as exploitation, lack of legal protection, broken social networks, poor health care and discrimination in the destination country can lead to mental illness [1]. Post migration mental health vulnerability increases if migration happens through informal channels or without proper documentation [2-5]. Nepali crossborder migrants to India could also be at risk of psychological morbidity due to irregular migration, lack of legal and social protections [6], and precarious working and living conditions $[7,8]$. However, there is scant information on the health and well-being of Nepali migrant workers in general [9] and on the cross-border migrants to India in particular. This study aimed to assess the magnitude and distribution of psychological morbidity in Nepali migrants returning from India.

\footnotetext{
* Correspondence: raja.dhungana@gmail.com

${ }^{1}$ Green Tara Nepal, Kathmandu, Nepal

${ }^{2}$ Institute for Health \& Sport (IHES), Victoria University, Melbourne, Australia

Full list of author information is available at the end of the article
}

(c) The Author(s). 2019 Open Access This article is distributed under the terms of the Creative Commons Attribution 4.0 International License (http://creativecommons.org/licenses/by/4.0/), which permits unrestricted use, distribution, and reproduction in any medium, provided you give appropriate credit to the original author(s) and the source, provide a link to the Creative Commons license, and indicate if changes were made. The Creative Commons Public Domain Dedication waiver (http://creativecommons.org/publicdomain/zero/1.0/) applies to the data made available in this article, unless otherwise stated. 
Context: open border, undocumented migration to India Nepal and India share an open border across which citizens can move freely without legal restrictions. This fact, combined with strong sociocultural affinity, has made India a major destination for Nepali labour migrants since the Anglo-Nepal war of 1814-15 [10]. India's recent economic growth and the fact that it offers better wages and employment opportunities than Nepal have acted as major pull factors, particularly for Nepali workers living in mid- and far-western border districts $[7,11]$. Poverty, unemployment and low wages are the most cited push factors for cross-border migration to India $[7,11]$.

Since neither registration nor obtaining labour permission is required for those going to India, cross-border migration is largely undocumented and, hence poorly understood [10]. Different studies and reports provide different estimates of the number of Nepali living in India, ranging from 0.5 to 3 million [6]. Recent estimates suggest that between $17 \%$ [12] and 37.6\% [13] of all Nepali migrants choose India as their destination. The majority of Nepali migrants to India were males (84\%) [13] and had either no or only primary education (68.3\%) [7]. Most were either security guards (48.6\%), restaurant workers $(13.1 \%)$ or wage labourers $(12.3 \%)$ [7]. Generally, it is the poorest, most marginalised semiskilled or unskilled Nepali workers who migrate from neighbouring districts in Nepal to India for work $[8,11]$.

Long delay in paying wages, unpaid overtime, lack of health insurance schemes, long working hours, lack of safety and security measures and poor hygiene are the major work, living and health related problems frequently encountered by Nepali workers in India [7]. Since most Nepali migrants are involved in the informal economy primarily as domestic workers, security guards, porters, coal miners, tea plantation and other farm workers and have no access to legal rights or security, it is claimed that Nepali migrants are taken as granted and are vulnerable to many forms of exploitation [6].

\section{Migration and mental health}

The preponderance of evidence suggests the migration is a stress-inducing phenomenon [14-16]. The migration process is associated with many complex interrelating psychological, social and cultural factors of both an individual and a collective nature [4, 17], all of which negatively affect people's psychological wellbeing $[15,18]$. Studies have demonstrated that non-migrant specific factors such as being female, poor socioeconomic status, low educational attainment and existing health conditions predict poor mental health in migrants $[2,15]$. Similarly, migrants who experienced abuse or exploitative treatment or perceived a lack of safety and security in the workplace had an increased risk of mental illness [14, 17, 19]. Additionally, cultural incongruity, alienation, lack of social support and migration related family stress during and after migration appear to make migrant workers more vulnerable to psychological distress [2, 4, 17].

Studies have found that migrants sometimes adopt coping strategies and develop resilience to address mental health stressors. Migrants who established their cultural identity and had socio-cultural support mechanisms were more able to avoid mental health threats in host countries $[14,19]$, a fact which signifies the importance of neighbourhood ethnic density, social cohesion and support and a smooth process of acculturation for protecting the psychological wellbeing in migrants $[15,20]$.

\section{Methods}

Data source, study participants and sampling

This study is part of a larger survey titled 'Health Vulnerabilities of Cross-border Migrants' [21]. The crosssectional survey was carried out in 2017-2018 with the support of the International Organization for Migration (IOM), Nepal and Green Tara Nepal (GTN) to explore the health vulnerabilities including psychological burden of cross-border migrants from Nepal.

The survey sample was representative of cross-border returnee migrants to India from Nepal. The study participants consisted of 751 returnee migrants who had worked at least six months in India before returning to Nepal. Initially, 24 clusters were selected randomly from Achham, Doti, Kailali, Kanchanpur, Banke, and Surkhet districts. In the absence of a sampling frame, the survey applied multiple non-probability sampling methods to maximize the selection of all households with returnee migrants in each cluster. When there were multiple eligible participants within a household, the survey applied the Kish grid method [22] to select just one individual. Details of the sampling procedure are mentioned elsewhere [21]. The survey obtained ethical clearance from the Ethical Review Board of Nepal Health Research Council and the participants provided written consent before data collection. The response rate of the participants was $99.3 \%$.

\section{Data collection}

The survey used a self-administered questionnaire to collect information about socio-demographic characteristics, work and living conditions, and health and behaviour from returnee migrants [21]. To assess psychological morbidity, the survey applied the General Health Questionnaire-12 (GHQ-12), which has been validated in Nepali [23]. Psychological morbidity was defined as the symptomatic presence of non-specific mental health problems, including psychological distress. 
Initially, we dichotomized the GHQ-12 item score as ' 0 ' for 0 and 1 , and ' 1 ' for 2 and 3 and aggregated each item value to get the overall score [23]. We defined the 'case-ness' of psychological morbidity based on a GHQ score six and above [23] and re-grouped age, marital status, ethnicity and other variables [Table 1]. We also extracted the standard definition for categorizing current smoking (smoking on at least one day during the past 30 days) [24] and current alcohol use (those who had had at least one drink of alcohol during the 30 days before the survey) [25] from the survey.

\section{Data analysis}

We performed data analysis using STATA Version 15.1 (Stata Corporation, College Station, TX, USA). Cases with missing values were deleted listwise. All estimates are presented with $95 \%$ confidence intervals (CIs). We tabulated findings related to the distribution of

Table 1 Association of socio-demographic and related factors with psychological morbidity

\begin{tabular}{|c|c|c|c|c|c|}
\hline \multicolumn{2}{|l|}{ Characteristics } & \multirow{2}{*}{$\begin{array}{l}\text { Frequency (\%) } \\
\text { Total }^{\natural}\end{array}$} & \multicolumn{2}{|c|}{ Psychological morbidity } & \multirow[t]{3}{*}{$p$ value } \\
\hline & & & Non-case-ness & Case-ness & \\
\hline & & n (\%) & n (\%) & n (\%) & \\
\hline \multirow[t]{4}{*}{ Age } & $<25$ years & $170(22.7)$ & $148(87.06)$ & $22(12.94)$ & \multirow[t]{4}{*}{$<0.001$} \\
\hline & $25-34$ years & $310(41.39)$ & $283(91.29)$ & $27(8.71)$ & \\
\hline & $35-44$ years & $190(25.37)$ & $164(86.32)$ & $26(13.68)$ & \\
\hline & 45 years and above & $79(10.55)$ & $53(67.09)$ & $26(32.91)$ & \\
\hline \multirow[t]{2}{*}{ Gender } & Male & $726(96.67)$ & $633(87.19)$ & $93(12.81)$ & \multirow[t]{2}{*}{$<0.001$} \\
\hline & Female & $25(3.33)$ & $17(68.0)$ & $8(32.0)$ & \\
\hline \multirow[t]{3}{*}{ Marital status } & Unmarried & $123(16.42)$ & $104(84.55)$ & $19(15.45)$ & \multirow[t]{3}{*}{0.006} \\
\hline & Married & $613(81.84)$ & $538(87.77)$ & $75(12.23)$ & \\
\hline & Others (widow, divorced) & $13(1.74)$ & $6(46.15)$ & $7(53.85)$ & \\
\hline \multirow[t]{5}{*}{ Education } & No Schooling & $102(13.58)$ & $75(73.53)$ & $27(26.47)$ & \multirow[t]{5}{*}{$<0.001$} \\
\hline & Primary and lower ( $1-5$ grades) & $236(31.42)$ & $200(84.75)$ & $36(15.25)$ & \\
\hline & Lower Secondary (6-8 grades) & $231(30.76)$ & $211(91.34)$ & $20(8.66)$ & \\
\hline & Secondary (9-10 grades) & $138(18.38)$ & $123(89.13)$ & $15(10.87)$ & \\
\hline & SLC and Higher & $44(5.86)$ & $41(93.18)$ & $3(6.82)$ & \\
\hline \multirow[t]{4}{*}{ Ethnicity } & Brahmin/Chhetri/Thakuri & $345(46.25)$ & $315(91.3)$ & $30(8.7)$ & \multirow[t]{4}{*}{$<0.001$} \\
\hline & Dalit and Janajatis Hill & $238(31.9)$ & $222(93.28)$ & $16(6.72)$ & \\
\hline & Dalit, Janajatis and others Terai & $144(19.3)$ & $99(68.75)$ & $45(31.25)$ & \\
\hline & Religious minorities & $19(2.55)$ & $12(63.16)$ & $7(36.84)$ & \\
\hline \multirow[t]{4}{*}{ Occupation } & Hotel worker & $209(28.32)$ & $191(91.39)$ & $18(8.61)$ & \multirow[t]{4}{*}{$<0.001$} \\
\hline & Factory worker & $208(28.18)$ & $172(82.69)$ & $36(17.31)$ & \\
\hline & Watchmen & $197(26.69)$ & $165(83.76)$ & $32(16.24)$ & \\
\hline & Others ${ }^{\bullet \Uparrow}$ & $124(16.8)$ & $110(88.71)$ & $14(11.29)$ & \\
\hline \multirow[t]{4}{*}{ Household income (monthly) (in ${ }^{\S}$ Nepali Rupee) } & $<10,000 \mathrm{NR}$ & $128(17.2)$ & $104(81.25)$ & $24(18.75)$ & \multirow[t]{4}{*}{0.035} \\
\hline & $10,000-19,999$ NR & $252(33.87)$ & $221(87.7)$ & $31(12.3)$ & \\
\hline & $20,000-29,999$ NR & 235 (31.59) & $215(91.49)$ & $20(8.51)$ & \\
\hline & $30,000 \mathrm{NR}$ and more & $129(17.34)$ & $105(81.4)$ & 24 (18.6) & \\
\hline \multirow{3}{*}{$\begin{array}{l}\text { Salary (monthly) } \\
\text { (in Indian Rupee }{ }^{\S \S} \text { ) }\end{array}$} & $<10,000$ IR & $202(27.08)$ & $166(82.18)$ & $36(17.82)$ & \multirow[t]{3}{*}{0.03} \\
\hline & $10,000-15,000$ IR & 469 (62.87) & $411(87.63)$ & $58(12.37)$ & \\
\hline & 15,001 IR and more & $75(10.05)$ & $70(93.33)$ & $5(6.67)$ & \\
\hline \multirow[t]{2}{*}{ Was with family ${ }^{\mathbf{9 9}}$} & Yes & 119 (16.35) & $98(82.35)$ & $21(17.65)$ & \multirow[t]{2}{*}{0.15} \\
\hline & No & $609(83.65)$ & $531(87.19)$ & $78(12.81)$ & \\
\hline
\end{tabular}

Note: `, Given the column wise total proportion to compare the frequency distribution within each group; ${ }^{\text {१⿻ }}$, other occupations were house servant, driver,

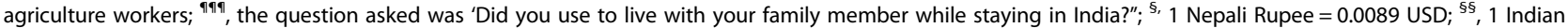
Rupee $=0.014$ USD 
psychological morbidity across socio-demographic, work and living conditions, and health and behavioural factors and used the Chi-square test to measure their association. To better understand the differences in the prevalence of psychological morbidity, we used Poisson regression analysis and reported the unadjusted/adjusted prevalence ratio (uPR/aPR) [26]. A $p$-value $<0.05$ is considered statistically significant. The independent variables that were significant ( $\mathrm{p}$-value $<0.05$ ) in univariate analysis were included in a multivariable model. As the household income had a strong correlation with the salary of the individual, the former variable was excluded from the adjusted model. After the listwise exclusion of the missing data, 571 out of 751 observations were available for multivariable analysis.

\section{Results}

\section{Demographic of sample}

The mean (standard deviation) and median (interquartile range) age of the participants were 32 years (9.2 years) and 31 years (25-38 years) respectively. Participants were overwhelmingly male (96.7\%) and a very high proportion $(81.8 \%)$ were married [Table 1]. Two thirds $(66.6 \%)$ had completed at least primary school as their highest level of education, and $13.6 \%$ had no formal schooling. Just over half (53.7\%) belonged to Dalit, Janajati, religious minority or disadvantaged caste groups. Most (83.2\%) fitted into one of three job-types: hotel worker, factory worker and guard [Table 1]. The majority of participants had household incomes (51.1\%) and salaries (72.5\%) less than 20,000 Nepali rupees (NR) or USD 178 per month (exchange rate, $1 \mathrm{NR}=0.0089 \mathrm{USD}$ ).

\section{Work and health conditions}

Three quarters of the participant (75.5\%) had worked more than eight hours a day and a large minority had had no day off (46\%) or sick leave provision (35.9\%) [Table 2]. Most participants (97.6\%) were either on vacation or had returned for personal reasons. The majority of the returnee migrants had spent less than two years in India during their last stay and were interested in going back again [Table 2].

More than half of the participants were current smokers or alcohol drinkers [Table 2]. Overall, $15.4 \%$ reported that they currently had at least one disease or medical condition, and over three-quarters $(76.7 \%)$ bore the treatment cost themselves [Table 2].

\section{Factors associated with psychological morbidity}

The prevalence of psychological morbidity was $13.5 \%$ (CI: 11.2-16.1\%). There were statistically significant differences in psychological morbidity by age, marital status, gender, education levels, ethnicity/caste, and income [Tables 1 and 2]. The data show that self-reported psychological morbidity was significantly higher in participants who were widowed/divorced $(\mathrm{uPR}=3.48 ; \mathrm{CI}=1.46$ 8.29), older ( $\mathrm{uPR}=2.54, \mathrm{CI}=1.44-4.49)$, female $=\mathrm{uPR} 2.5$; $\mathrm{CI}=1.21-5.14)$, Dalit, Janajatis and others from the Terai $(\mathrm{uPR}=3.6, \mathrm{CI}=2.26-5.7)$, religious minorities $(\mathrm{uPR}=$ 4.24, $\mathrm{CI}=1.86-9.65)$, factory workers $(\mathrm{uPR}=2.0, \mathrm{CI}=$ $1.14-3.54)$, security guards $(\mathrm{uPR}=1.89, \mathrm{CI}=1.06-3.36$ ) and poor (monthly household income <10,000 NR) [Table 3]. The adjusted regression analysis showed that participants aged 45 years or above were 2.74 times $(\mathrm{aPR}=$ 2.74, CI: 1.01-7.41) more likely to suffer from psychological morbidity than participants aged 25 years or younger [Table 3]. Similarly, the prevalence of psychological morbidity among Dalits and Janajatis from the Terai $(\mathrm{aPR}=3.29, \mathrm{CI}: 1.6-6.74)$ and minority groups $(\mathrm{aPR}=$ 3.64, CI: 1.02-13.14) was more than three times higher than the prevalence among the caste group Brahmin/ Chhetri/Thakuri.

Self-reported psychological morbidity was not associated with the number of hours worked per day, the provision of days off, and the length of time stayed in India. However, there was a statistically significant association between psychological morbidity and having sick leave: not having sick leave doubled the rates of selfreported psychological morbidity $(\mathrm{aPR}=2.4, \mathrm{CI}=1.32$ 4.34). Returning home for personal work $(\mathrm{aPR}=1.96$, $\mathrm{CI}=1.01-3.83)$ and other reasons, for example, the end of one's contract ( $\mathrm{aPR}=4.06, \mathrm{CI}=1.08-15.28)$, was also associated with high levels of psychological morbidity.

Similarly, participants with pre-existing health problems were twice $(\mathrm{aPR}=2)$ as likely as other participants to report psychological morbidity. Current alcohol use ( $\mathrm{uPR}=0.53, \mathrm{CI}=0.35-0.79)$ and having had sex in previous six months (uPR $=0.48, \mathrm{CI}=0.32-0.71)$ were associated with low psychological morbidity in univariate analysis, but this association did not remain intact in multivariable analysis [Table 3]. Likewise, participants who had experienced no difficulties in accessing health facilities in the host country were likely to have a lower level of psychological morbidity $(\mathrm{aPR}=0.53, \mathrm{CI}=0.3-$ 0.93 ) than those without such easy access. Neither smoking tobacco nor smoking marijuana was significantly associated with an increase in self-reported mental health issues.

\section{Discussion}

This study assessed the prevalence of and factors associated with psychological morbidity in Nepali cross-border migrants to India. We found that the burden of selfreported psychological morbidity was significant among the study population and associated with age, gender, ethnicity, education and income. The prevalence of psychological morbidity was significantly higher in participants with an existing health condition, those who had 
Table 2 Association of work and health related factors with psychological morbidity

\begin{tabular}{|c|c|c|c|c|c|}
\hline \multirow[t]{2}{*}{ Characteristics } & & \multirow{2}{*}{$\begin{array}{l}\text { Frequency (\%) } \\
\text { Total }\end{array}$} & \multicolumn{2}{|c|}{ Psychological morbidity } & \multirow[t]{2}{*}{$p$ value } \\
\hline & & & Non-case-ness & Case-ness & \\
\hline & & n (\%) & $\mathrm{n}(\%)$ & n (\%) & \\
\hline \multirow[t]{2}{*}{ Working hours/day } & $8 \mathrm{~h}$ and less & $184(24.5)$ & $161(87.5)$ & $23(12.5)$ & 0.66 \\
\hline & $>8 \mathrm{~h}$ & $567(75.5)$ & $489(86.24)$ & $78(13.76)$ & \\
\hline \multirow[t]{2}{*}{ Day off } & Yes & $341(45.96)$ & $299(87.68)$ & $42(12.32)$ & 0.39 \\
\hline & No & $401(54.04)$ & $343(85.54)$ & $58(14.46)$ & \\
\hline \multirow[t]{2}{*}{ Sick leave } & Yes & $466(64.1)$ & $423(90.77)$ & $43(9.23)$ & $<0.001$ \\
\hline & No & $261(35.9)$ & $211(80.84)$ & $50(19.16)$ & \\
\hline \multirow[t]{4}{*}{ Duration of last stay in India } & $<12$ months & $419(56.47)$ & $98(82.35)$ & $21(17.65)$ & 0.28 \\
\hline & 12-23 months & $241(32.48)$ & $531(87.19)$ & $78(12.81)$ & \\
\hline & 24-35 months & $50(6.78)$ & $44(88.0)$ & $6(12.0)$ & \\
\hline & 36 months and later & $32(4.31)$ & $25(78.13)$ & $6(21.87)$ & \\
\hline \multirow[t]{3}{*}{ Reason for return } & Holiday & $348(52.02)$ & $330(94.83)$ & $18(5.17)$ & $<0.001$ \\
\hline & Personal problems ${ }^{19}$ & $305(45.59)$ & $248(81.31)$ & $57(18.69)$ & \\
\hline & Others (end of contract, political issues) & $16(2.39)$ & $11(68.75)$ & $5(31.25)$ & \\
\hline \multirow[t]{2}{*}{ Going back } & Yes & $607(81.59)$ & $540(83.59)$ & $67(11.04)$ & $<0.001$ \\
\hline & No & $137(18.41)$ & $106(68.37)$ & $31(31.63)$ & \\
\hline \multirow[t]{2}{*}{ Current smoker } & Yes & $415(55.41)$ & $359(86.51)$ & $56(13.49)$ & 0.89 \\
\hline & No & $334(44.59)$ & $290(86.83)$ & $44(13.17)$ & \\
\hline \multirow[t]{2}{*}{ Current alcohol user } & Yes & $429(57.12)$ & $387(90.21)$ & $42(9.79)$ & 0.001 \\
\hline & No & $322(42.88)$ & $263(81.68)$ & $59(18.32)$ & \\
\hline \multirow[t]{2}{*}{ Smoke marijuana } & Yes & $32(4.27)$ & $25(78.13)$ & $7(21.88)$ & 0.15 \\
\hline & No & $718(95.73)$ & $624(86.91)$ & $94(13.09)$ & \\
\hline \multirow[t]{2}{*}{ Sex in last 6 months } & Yes & $502(67.20)$ & $452(90.04)$ & $50(9.96)$ & $<0.001$ \\
\hline & No & $245(32.80)$ & $194(79.18)$ & $51(20.82)$ & \\
\hline \multirow[t]{2}{*}{ Existing health problem ${ }^{\S}$} & Yes & $114(15.36)$ & $76(66.67)$ & $38(33.33)$ & $<0.001$ \\
\hline & No & $628(84.64)$ & $566(90.13)$ & $62(9.87)$ & \\
\hline \multirow[t]{2}{*}{ Accessing healthcare } & Difficult to access & $197(28.84)$ & $153(77.66)$ & $44(22.34)$ & $<0.001$ \\
\hline & Easy to access & $486(71.16)$ & $446(91.77)$ & $40(8.23)$ & \\
\hline \multirow[t]{3}{*}{ Health expense coverage } & Completely by employer & $54(11.04)$ & $46(85.19)$ & $8(14.81)$ & 0.02 \\
\hline & Partially by employer & $60(12.27)$ & $57(95.0 \%)$ & $3(5.0 \%)$ & \\
\hline & Completely by myself & $375(76.69)$ & $302(80.53)$ & $73(19.47 \%)$ & \\
\hline \multirow[t]{3}{*}{ Healthcare expense } & Easy to manage & $313(42.07)$ & $288(92.01)$ & $25(7.99)$ & $<0.001$ \\
\hline & Somehow manageable & $311(41.8)$ & $269(86.5)$ & $42(13.5)$ & \\
\hline & Very difficult to manage & $120(16.13)$ & 87 (72.5) & $33(27.5)$ & \\
\hline
\end{tabular}

Note: ", Given the column wise total proportion to compare the frequency distribution within each group; " , personal problem includes poor health and family issues; $_{\text {ๆศศ }}$, the question asked was 'Do you intention to return to India for job?"; ${ }^{\S}$, the question asked was 'Do you have any physical health problem? are you taking any medication currently?'

difficulty accessing health care, and those whose jobs had no provision for sick leave. This study, however, failed to incorporate some key variables that could affect the mental health status in migrant workers, such as social support, cohesion and cultural conflict in the host country.

The present study found that self-reported psychological morbidity (GHQ-12 score $\geq 6$ ) was present in
$13.5 \%$ of the participants. This finding is comparable to that of a study conducted in a similar setting with similar study participants [7], in which $24.4 \%$ of Bangladeshi and $15.1 \%$ of Nepali returnee migrants showed some level of distress (undichotomized GHQ-12 score > 20). The proportion of the participants having an undichotomized GHQ-12 score $>20$ in our study is $20.2 \%$. There is a paucity of Nepali studies that measure psychological 
Table 3 Multivariable analysis for psychological morbidity

\begin{tabular}{|c|c|c|c|}
\hline \multirow[t]{2}{*}{ Characteristics } & & \multicolumn{2}{|l|}{ Prevalence ratio } \\
\hline & & UPR (Cl) & aPR (Cl) \\
\hline \multirow[t]{4}{*}{ Age } & $<25$ years & Reference & \\
\hline & $25-34$ years & $0.67(0.38-1.18)$ & $0.71(0.29-1.72)$ \\
\hline & $35-44$ years & $1.06(0.58-1.87)$ & $0.82(0.31-2.19)$ \\
\hline & 45 years and above & $2.54(1.44-4.49)^{* *}$ & $2.74(1.01-7.41)^{*}$ \\
\hline \multirow[t]{2}{*}{ Gender } & Male & Reference & \\
\hline & Female & $2.5(1.21-5.14)^{* * *}$ & $0.77(0.19-3.12)$ \\
\hline \multirow[t]{3}{*}{ Marital status } & Unmarried & Reference & \\
\hline & Married & $0.79(0.49-1.31)$ & $0.69(0.28-1.66)$ \\
\hline & Others (widow, divorced) & $3.48(1.46-8.29)^{* *}$ & $1.16(0.14-9.9)$ \\
\hline \multirow[t]{5}{*}{ Education } & No Schooling & Reference & \\
\hline & Primary & $0.58(0.35-0.95)^{*}$ & $1.62(0.72-3.65)$ \\
\hline & Lower Secondary & $0.33(0.18-0.58)^{* * *}$ & $0.72(0.26-1.98)$ \\
\hline & Secondary & $0.41(0.22-0.77)^{* *}$ & $1.2(0.41-3.55)$ \\
\hline & SLC and Higher & $0.25\left((0.08-0.85)^{*}\right.$ & $1.0(0.18-5.76)$ \\
\hline \multirow[t]{4}{*}{ Ethnicity } & Brahmin/Chhetri/Thakuri & Reference & \\
\hline & Dalit and Janajatis Hill & $0.77(0.42-1.42)$ & $0.45(0.19-1.06)$ \\
\hline & Dalit, Janajatis and others Terai & $3.6(2.26-5.7)^{* * *}$ & $3.29(1.6-6.74)^{* *}$ \\
\hline & Religious minorities & $4.24(1.86-9.65)^{* *}$ & $3.64(1.02-13.14)^{*}$ \\
\hline \multirow[t]{4}{*}{ Occupation } & Hotel worker & Reference & \\
\hline & Factory worker & $2.0(1.14-3.54) *$ & $1.12(0.46-3.03)$ \\
\hline & Watchmen & $1.89(1.06-3.36)^{*}$ & $1.35(0.54-3.42)$ \\
\hline & Others 9 & $1.31(0.65-2.64)$ & $1.65(0.62-4.42)$ \\
\hline \multirow[t]{3}{*}{ 91Salary/month } & $<10,000$ INR & Reference & \\
\hline & $10,000-15,000 \mathrm{IR}$ & $0.69(0.44-1.07)$ & $0.88(0.46-1.66)$ \\
\hline & 15,001 IR and more & $0.37(0.14-0.95)^{*}$ & $0.41(0.14-1.19)$ \\
\hline \multirow[t]{2}{*}{ Sick leave } & Yes & Reference & \\
\hline & No & $2.08(1-38-3.12)^{* * *}$ & $2.4(1.32-4.34)^{* *}$ \\
\hline \multirow[t]{3}{*}{ Reason for return } & Holiday & Reference & \\
\hline & Personal problems & $3.61(2.13-6.14)^{* * *}$ & $1.96(1.01-3.83)^{*}$ \\
\hline & Others (end of contract, political issues) & $6.04(2.24-16.27)^{* * *}$ & $4.06(1.08-15.28)^{*}$ \\
\hline \multirow[t]{2}{*}{ Going back ${ }^{\S}$} & Yes & Reference & \\
\hline & No & $2.05(1-34-3.14)^{*}$ & $1.23(0.67-2.25)$ \\
\hline \multirow[t]{2}{*}{ Existing health problem $\$ \S$} & Yes & Reference & \\
\hline & No & $0.3(0.2-0.44)^{* * *}$ & $0.50(0.28-0.93)^{*}$ \\
\hline \multirow[t]{2}{*}{ Current alcohol user } & Yes & Reference & \\
\hline & No & $1.87(1.26-2.78)^{* * *}$ & $0.99(0.53-1.84)$ \\
\hline \multirow[t]{2}{*}{ Sex in last 6 months } & Yes & Reference & \\
\hline & No & $2.08(1.41-3.08)^{* * *}$ & $1.21(0.62-2.37)$ \\
\hline \multirow[t]{2}{*}{ Accessing healthcare } & Difficult to access & Reference & \\
\hline & Easy to access & $0.37(0.24-0.57)^{* * *}$ & $0.53(0.3-0.93)^{*}$ \\
\hline
\end{tabular}


morbidity using GHQ-12 tool with the same cut-off point (GHQ-12 score $\geq 6$ ) as ours, but one study carried out in rural Nepal found that $9.8 \%$ of postnatal mothers experienced psychological morbidity [27]. Other studies estimated different psychological parameters such as anxiety and depression using tools other than the GHQ-12 and reported a wide range of findings [28-31]. A recent mental health prevalence survey in Nepal, for instance, found that $12.9 \%$ of Nepali had at least one mental disorders [32], while a survey of health problems of Nepali female migrant workers in the Middle-East and Malaysia reported that $8.7 \%$ women had mental health problems [33]. Likewise, studies conducted outside of Nepal also demonstrated the high burden of anxiety and depression among labour migrants [34]. The prevalence of anxiety and depression pooled from nine studies conducted among labour migrants in the USA, France and Uganda were 21\% (CI:14-29\%) and 20\% (CI: 14-26\%) [34] respectively. A recent systematic review identified 37 studies related to migration and mental health that had been conducted in low-and middle-income countries, where four of those studies reported the prevalence of depression to be between 3 and 51\% [14].

The prevalence of psychological morbidity varied significantly by age, gender, ethnicity, education, occupation and household income among our study participants. It is generally observed that the rate of psychological illness is raised in advancing age [35] and is higher in females $[15,36,37]$. De Maio and Kemp also noticed an increased likelihood of deterioration of mental health among Canadian female immigrants [37]. The findings are consistent with a community-based study of a general population in Nepal [29], which found that age, gender and ethnicity were associated with higher depression and anxiety parameters [29]. One possible explanation for the high rate of psychological morbidity among Dalit and Janajati migrants from the Terai is the persistent poverty in the region. The Terai has a low Human Development Index (HDI) compared to the rest of the country (the mountain and hill regions) due to low literacy, income and life expectancy [38]. Furthermore, Nepali Dalits are more likely to be exposed to health, family, financial and political stressful life events than other castes/ethnic groups (Brahman, Chhetri and Janajatis) leaving them susceptible to depression and anxiety [29]. A wealth of literature demonstrated an inverse relationship between low socio-economic status and psychological wellbeing $[15,37,39]$. Setia et al. found that male immigrants in Canada with low incomes had nearly a two-fold risk (OR: 1.99, 95\% CI: 1.38-2.86) of having severe psychological distress than immigrants in higher income categories [39].

This study did not find a statistically significant association between work-related conditions such as working hours and day off and psychological morbidity. However, the prevalence of psychological morbidity differed noticeably depending on whether or not migrants had a provision for sick leave in their last job. Similarly, rates of psychological morbidity did not vary much with the duration of migrants' stay in India. That said, rates were significantly higher among those who returned home because of personal issues at home or the termination of contract in India. A study conducted among returnee Nepali and Bangladeshi migrants reported that study participants returned home mostly due to personal issues (poor health, family problems) and exhibited high psychological distress [7].

The findings indicated that pre-existing physical illness was linked to psychological morbidity in the study population. Moreover, most of the existing health problems among the study participants were related to chronic conditions such as diabetes, hypertension and chronic obstructive pulmonary diseases; all are diseases associated with psychological co-morbidity [40]. This finding is consistent with a study conducted among Romanian immigrants in Italy that showed the odds of experiencing psychological distress was 6 times higher among migrants suffering from chronic diseases than among those who were not [41].

In contradiction to the factors amplifying psychological morbidity, cultural closeness between Nepal and India could possibly help minimize cultural conflicts and might have a protective effect on the mental health of Nepali migrants [42, 43]. However, it is difficult to ascertain why living with family members (a proxy variable for family support) was not significantly associated with a lower rate of psychological morbidity.

Overall, the present study demonstrated that psychological morbidity is prevalent among Nepali crossborder migrants to India and particularly affects the special groups [44], such as older adults, women, Dalit and Janajati from marginalized areas and religious minority. Similarly, work and health related factors, for example, provision of sick leave, pre-existing physical illness and difficulty in accessing health services were significantly associated with psychological morbidity among the study participants. The findings suggest a need for resilience enhancing responses such as establishing legal frameworks to protect the rights of migrants including the right to health care and other social services in the destination country $[1,45,46]$. Evidence shows that culturally appropriate and contextualized psychosocial support interventions can also be effective for promoting mental health in a particular group of migrants [47]. Similarly, as suggested by Davies et al. [48], returnee migrants should also be re-integrated into the existing healthcare system for psychological support and proper management of other health conditions including tuberculosis. 
If they do not receive such care, the stigma attached to the explanatory model of mental illness prevalent in society may further delay in psychological help seeking among migrants [49]. The preliminary draft of Nepal's migration health policy also speaks about monitoring migrants' health at different stages of migration and guides action to control the elevated risk of the crossborder transmission of communicable diseases. It is not clear how the policy helps address the health challenges incurred due to the current recordless, undocumented cross-border migration between Nepal and India or facilitates the integration and re-integration of these migrants into migrant specific and sensitive programs and policies in the destination and home countries.

This study has some methodological limitations. Despite the random selection of clusters, the survey applied non-probability sampling for selecting households. For this reason, the findings should be generalized beyond the study participants only with caution. Similarly, the GHQ-12 used in the study is a screening tool, not a diagnostic aid for psychological morbidity. Moreover, the tool was validated quite a long ago (in 1999) [23] and the high cut off value ( $\geq 6$ GHQ-12 score) might have resulted in the underestimation of psychological morbidity in the study population. Likewise, information obtained from returnee migrants may not well represent current migrants working in India. As participants were selected from among those who declared themselves cross-border migrants, the sample was not very likely to have included the participants who had been involved in socially stigmatized and undesirable employment such as sex work. Lastly, because of the study's cross-sectional design, establishing the causal relationship between the study and outcome variables is beyond its scope.

\section{Conclusion}

This study assessed the prevalence and associated factors of psychological morbidity among Nepali cross border migrants who had returned from India. The findings showed the burden of psychological morbidity was significantly high among vulnerable groups such as women, the elderly, marginalized groups and minorities. The respondent's self-reported psychological condition was associated with work and health related factors. In addition to offering insights into migrant's psychological ill health, the findings point to the need for tailoring migrant specific mental health promotive interventions and strengthening the legal framework for providing rights and social securities to Nepali cross border migrants in India.

\section{Acknowledgments}

We appreciate all the support and feedback provided by Dr. Rama Ramisetty Venkata, IOM; Bishwa Rai, IOM; Dr. Patrick Duigan, IOM; Jhabindra Bhandari,
IOM; Ram Chandra Silwal, GTN, and Nagendra Luitel, TPO Nepal. We would like to thank all participants who took part in the survey.

\section{Authors' contributions}

RRD conceptualized the study, analyzed the data, interpreted the findings and prepared the first draft. RK, NA, PA, PRR and EVT interpreted and provided input for preparing the first draft of the manuscript. BD, GNS, KW and PS reviewed and revised the final draft of the manuscript. All authors read and approved the final manuscript.

\section{Funding}

The study was funded by the International Organization for Migration, Nepal.

\section{Availability of data and materials}

The data used to support the findings of this study are available from the corresponding author upon request.

\section{Ethics approval and consent to participate}

Ethical approved was obtained from the Ethical Review Board of Nepal Health Research Council. A written informed consent was obtained from each respondent before the data collection. Participants were informed about their voluntary participation and ensured the protection of privacy and confidentiality. Participants having symptoms of severe chronic and infectious diseases such as heart diseases and tuberculosis were referred to nearby government hospitals.

\section{Consent for publication}

Not applicable.

\section{Competing interests}

Prof Edwin van Teijlingen, a member of the editorial board (Associate Editor) for BMC Pregnancy and Childbirth, is also a co-author of this article.

\section{Author details}

${ }^{1}$ Green Tara Nepal, Kathmandu, Nepal. ${ }^{2}$ Institute for Health \& Sport (IHES), Victoria University, Melbourne, Australia. ${ }^{3}$ Faculty of Health \& Social Sciences, Bournemouth University, Bournemouth, UK. ${ }^{4}$ School of Public Health, University of California, Berkeley, USA. ${ }^{5}$ International Organization for Migration, Kathmandu, Nepal. ${ }^{6}$ Ministry of Health and Population, Kathmandu, Nepal. ${ }^{7}$ International Organization for Migration, Geneva, Switzerland. ${ }^{8}$ International School of Health and Human Science, The University of Huddersfield, Huddersfield, UK.

Received: 20 May 2019 Accepted: 1 November 2019

Published online: 15 November 2019

\section{References}

1. Vulnerability and resilience [https://www.iom.int/sites/default/files/our_ work/DMM/Migration-Health/Vulnerability\%20and\%20Resilience\%2 Opaper\%20excerpts_\%20final.pdf].

2. Bhugra D. Migration and mental health. Acta Psychiatr Scand. 2004;109(4): 243-58.

3. International Labour Organization (ILO): Global Alliance against Forced Labour: Global Report under the Follow-up to the ILO Declaration on Fundamental Principles and Rights at Work. International Labour Office, Geneva: ILO; 2005. https://www.lo.org/public/english/standards/relm/ilc/ ilc93/pdf/rep-i-b.pdf.

4. Zimmerman C, Hossain M, Watts C. Human trafficking and health: a conceptual model to inform policy, intervention and research. Soc Sci Med. 2011;73(2):327-35.

5. Meyer SR, Robinson WC, Chhim S, Bass JK. Labor migration and mental health in Cambodia: a qualitative study. J Nerv Ment Dis. 2014;202(3):200-8.

6. Sharma S, Thapa D. Taken for Granted: Nepali Migration to India. Kathmandu: Centre for the Study of Labour and Mobility; 2013. https:// www.ceslam.org/uploads/backup/Taken\%20for\%20Granted\%20Nepai\%2 OMigration\%20to\%20India.pdf.

7. Sharma V, Saraswati LR, Rob U, Puri M, Sarna A. Life across the border: Migrants in South Asia. New Delhi: Population Council; 2015.

8. Sharma S, Pandey S, Pathak D, Sijapati-Basnett B. State of migration in Nepal. Kathmandu: Centre for the Study of Labour and Mobility; 2014. 
9. Simkhada PP, Regmi PR, van Teijlingen E, Aryal N. Identifying the gaps in Nepalese migrant workers' health and well-being: a review of the literature. J Travel Med. 2017:24(4).

10. Department of Foreign Employment: Labour Migration for Employment- A Status Report for Nepal: 2013/2014. Kathmandu: Ministry of Labour and Employment, Government of Nepal; 2015. https:/asiafoundation.org/ resources/pdfs/MigrationReportbyGovernmentofNepal.pdf.

11. Shrestha M. Push and Pull: A Study of International Migration from Nepal. Kathmandu: Social Protection and Labor Global Practice Group; 2017.

12. Ministry of Health (MoH), New ERA, ICF: Nepal demographic and health survey, 2016. Kathmandu: MoH, Nepal; 2017. https://www.dhsprogram.com/ pubs/pdf/fr336/fr336.pdf

13. Central Bureau Of Statistics (CBS) Nepal: National population and housing census 2011. Kathmandu: CBS; 2012. https://cbs.gov.np/national-populationand-housing-census-2011 national-report/.

14. Meyer SR, Lasater M, Tol WA. Migration and mental health in low- and middle-income countries: a systematic review. Psychiatry. 2017;80(4):374-81.

15. Butler M, Warfa N, Khatib Y, Bhui K. Migration and common mental disorder: an improvement in mental health over time? Int Rev Psychiatry. 2015;27(1):51-63.

16. Chen W, Hall BJ, Ling L, Renzaho AM. Pre-migration and post-migration factors associated with mental health in humanitarian migrants in Australia and the moderation effect of post-migration stressors: findings from the first wave data of the BNLA cohort study. Lancet Psychiatry. 2017;4(3):218-29.

17. Pitambar Koirala KG, Upasana Regmi, Nirjala Sharma, Suraj Koirala: Psychological and Socio-Cultural Impacts, Kathmandu, Nepal: Transcultural Psychosocial Organization; 2017.

18. Virupaksha HG, Kumar A, Nirmala BP. Migration and mental health: an interface. J Nat Sci Biol Med. 2014;5(2):233-9.

19. Anbesse B, Hanlon C, Alem A, Packer S, Whitley R. Migration and mental health: a study of low-income Ethiopian women working in middle eastern countries. Int J Soc Psychiatry. 2009:55(6):557-68.

20. Arevalo SP, Tucker KL, Falcon LM. Beyond cultural factors to understand immigrant mental health: neighborhood ethnic density and the moderating role of pre-migration and post-migration factors. Soc Sci Med. 2015:138:91-100

21. Adhikary P, Aryal N, Dhungana RR, Migrant Workers' Health Research Consortium: Health Vulnerabilities of Cross-border Migrants from Nepal. Kathmandu: International Organization for Migration; 2018. https://nepal. iom.int/sites/default/files/publication/Research_on_The_Health_ Vulnerabilities_of_The_Cross_Border_Migrants_from_Nepal_0.pdf.

22. World Health Organization. WHO STEPS surveillance manual. Geneva: World Health Organization; 2008.

23. Koirala NR, Regmi SK, Sharma VD, Khalid A, Nepal MK. Sensitivity and validity of the general health questionnaire (GHQ-12) in a rural community setting in Nepal. Nepalese J Psychiatry. 1999;1(1):34-40.

24. Indicator Definitions - Tobacco [https://www.cdc.gov/cdi/definitions/ tobacco.html]

25. Indicator Definitions - Alcohol [https://www.cdc.gov/cdi/definitions/ alcohol.html].

26. Barros AJ, Hirakata VN. Alternatives for logistic regression in cross-sectional studies: an empirical comparison of models that directly estimate the prevalence ratio. BMC Med Res Methodol. 2003;3(1):21.

27. Clarke K, Saville N, Shrestha B, Costello A, King M, Manandhar D, Osrin D, Prost A. Predictors of psychological distress among postnatal mothers in rural Nepal: a cross-sectional community-based study. J Affect Disord. 2014;156:76-86.

28. Khattri JB, Nepal MK. Study of depression among geriatric population in Nepal; 2006

29. Kohrt BA, Speckman RA, Kunz RD, Baldwin JL, Upadhaya N, Acharya NR, Sharma VD, Nepal MK, Worthman CM. Culture in psychiatric epidemiology: using ethnography and multiple mediator models to assess the relationship of caste with depression and anxiety in Nepal. Ann Hum Biol. 2009;36(3):261-80.

30. Risal A, Manandhar K, Linde M, Steiner TJ, Holen A. Anxiety and depression in Nepal: prevalence, comorbidity and associations. BMC Psychiatry. 2016;16(1):102.

31. Upadhyaya KD, Pol K. A mental health prevalence survey in two developing towns of western region. Journal of Nepal Medical Association. 2003; 42(150):328-30.

32. Jha AK, Ojha SP, Dahal S, Sharma P, Pant SB, Labh S, Marahatta K, Shakya S, Adhikari RP, Joshi D, et al. Prevalence of mental disorders in Nepal: findings from the pilot study. J Nepal Health Res Counc. 2019;17(2):141-7.
33. Simkhada P, van Teijlingen E, Gurung M, Wasti SP. A survey of health problems of Nepalese female migrants workers in the Middle-East and Malaysia. BMC Int Health Human Rights. 2018;18(1):4.

34. Lindert J, Ehrenstein OS, Priebe S, Mielck A, Brahler E. Depression and anxiety in labor migrants and refugees--a systematic review and metaanalysis. Soc Sci Med. 2009;69(2):246-57.

35. Minas H. Migration and mental health. Transcult Psych Unit Report: Melbourne; 1999.

36. Pannetier J, Lert F, Jauffret Roustide M, du Loû AD. Mental health of subsaharan african migrants: the gendered role of migration paths and transnational ties. SSM - population health. 2017:3:549-57.

37. De Maio FG, Kemp E. The deterioration of health status among immigrants to Canada. Glob Public Health. 2010:5(5):462-78.

38. National Planning Commission. Nepal Human Development Report 2014. vol. 142. Kathmandu: Government of Nepal; 2014.

39. Setia MS, Quesnel-Vallee A, Abrahamowicz M, Tousignant P, Lynch J. Different outcomes for different health measures in immigrants: evidence from a longitudinal analysis of the National Population Health Survey (1994-2006). J Immigr Minor Health. 2012;14(1):156-65.

40. Clarke DM, Currie KC. Depression, anxiety and their relationship with chronic diseases: a review of the epidemiology, risk and treatment evidence. Med J Aust. 2009;190(7):S54.

41. Tarricone I, Atti AR, Salvatori F, Braca M, Ferrari S, Malmusi D, Berardi D. Psychotic symptoms and general health in a socially disadvantaged migrant community in Bologna. Int J Soc Psychiatry. 2009;55(3):203-13.

42. Bhugra D, Becker MA. Migration, cultural bereavement and cultural identity. World psychiatry : official journal of the World Psychiatric Association (WPA). 2005;4(1):18-24

43. Kumar R. India-Nepal open border: springboard for opportunities. Int Stud. 2016;50(1-2):165-83.

44. Bhugra D, Gupta S, Bhui K, Craig T, Dogra N, Ingleby JD, Kirkbride J, Moussaoui D, Nazroo J, Qureshi A, et al. WPA guidance on mental health and mental health care in migrants. World psychiatry : official journal of the World Psychiatric Association (WPA). 2011;10(1):2-10

45. Benach J, Muntaner C, Delclos C, Menendez M, Ronquillo C. Migration and "low-skilled" workers in destination countries. PLoS Med. 2011;8(6):e1001043.

46. Abubakar I, Aldridge RW, Devakumar D, Orcutt M, Burns R, Barreto ML, Dhavan P, Fouad FM, Groce N, Guo Y, et al. The UCL-Lancet Commission on migration and health: the health of a world on the move. Lancet. 2018; 392(10164):2606-54

47. Siriwardhana C, Stewart R. Forced migration and mental health: prolonged internal displacement, return migration and resilience. Int Health. 2013;5(1):19-23.

48. Davies AA, Borland RM, Blake C, West HE. The dynamics of health and return migration. PLoS Med. 2011;8(6):e1001046.

49. Kohrt BA, Hruschka DJ. Nepali concepts of psychological trauma: the role of idioms of distress, ethnopsychology and ethnophysiology in alleviating suffering and preventing stigma. Cult Med Psychiatry. 2010;34(2):322-52

\section{Publisher's Note}

Springer Nature remains neutral with regard to jurisdictional claims in published maps and institutional affiliations.

Ready to submit your research? Choose BMC and benefit from:

- fast, convenient online submission

- thorough peer review by experienced researchers in your field

- rapid publication on acceptance

- support for research data, including large and complex data types

- gold Open Access which fosters wider collaboration and increased citations

- maximum visibility for your research: over $100 \mathrm{M}$ website views per year

At BMC, research is always in progress.

Learn more biomedcentral.com/submissions 